УДК 821.163.41.09-31 Pavlović, Ž. https://doi.org/10.18485/godisnjak.2016.11.15

Наталија П. Јовановић* Универзитет у Београду

Филолошки факултет, докторанд
Оригинални научни рад

Примљен: 05. 10. 2016.

Прихваћен: 20. 10. 2016.

\title{
„ЗЛОУПОТРЕБА” ТЕЛА - ИШЧЕЗНУЋЕ КАО СТРАСТ У РОМАНУ ЗАДАХ ТЕЛА ЖИВОЈИНА ПАВЛОВИЋА
}

[...] odnos prema erotici više imam u batajevskom smislu, kroz osećaj da je to jedna sila koja, da čovek nije svesno biće, ne bi bila po njega pogubna. A seks je upravo oblast u kojoj se on najviše udaljava od sebe kao svesnog bića, u kojoj učestvuje u primicanju nečemu što je domen strave i iščeznuća (Павловић 2001: 107-108).

У раду ће бити представљен однос између тела, сексуалности и ништавила који је тематизован у једном поглављу романа Задах тела Живојина Павловића. Указаћемо на положај тела у роману и начине развијања мисли о телесности, као и кључна места аутентичне филозофије тела коју ствара главни јунак. Обратићемо пажњу на везу између сексуалности, гађења и (ауто)деструктивности и закључити да се, посматрано из перспективе главног јунака, до апсолутне слободе долази њиховим обједињењем.

Кључне речи: тело, сексуалност, ништавило, апсолутна слобода, гађење, Задах тела.

\section{1. Тело које говори}

Задах тела јесте роман који је међу критичарима у великој мери избегаван јер је опасан. Опасност долази не само отуда што је то роман о стајању на ивици, већ и зато што и од тумача захтева стајање на истој ивици, што је позиција непријатне изложености. Павловић јесте експли-

*njnatalijajovanovic@gmail.com 
цитан писац, а када то кажемо, мислимо да се не стиди тела и речи о телу. Наслов Задах тела јасно показује да ћемо ући у подручје телесности, али наслов прећуткује да ћемо истовремено ући у простор промишљања тела. Од телесности се, на врхунцу романа, у Славољубовој провокативној исповести, ствара цео филозофски систем. Треба одмах разјаснити да је у Павловићевој прози свако промишљање тела мушко промишљање тела. Женска перспектива остаје недоступна и жена је увек сведена на објекат. ${ }^{1}$ Мисао и тело код Павловића нису насилно одељени као што је најчешће случај у књижевности, али и у историји филозофске мисли. Приповедач се у описима не зауставља тамо где се може прећи граница порнографског, већ ту границу релативизује, а да би је уопште могао релативизовати, прво је мора прекорачити. Једино на овај начин може се схватити сексуалност као феномен, што и јесте једна од кључних тема његове прозе, јер, као што Јулија Кристева истиче, сексуалност не постоји одвојена од језика. (Кристева 1987: 46)

\section{2. Уживање и апсолутна слобода - тело које бира сада}

Славољуб је модерни човек нихилиста, близак Камијевом Мерсоу, без идеала, стега и свести о будућности или прошлости, које жели да негира како би активно живео у садашњости. Живљење у садашњости подразумева постојање засновано на ослушкивању нагона и импулса сопственог тела. Уз то, искључивање будућности као идеала коме се тежи, имплицитно подразумева и брисање идеје о постојању смисла живота. Слично као што је то случај и код његовог стрица Шањија у првом поглављу, Славољубов циљ, ако желимо да говоримо у категорији циљева, јесте да доживи оргазам, такозвану „малу смрт”. Пошто је Шањи фокусиран на женски полни орган који доживљава као гроб, рупу која истовремено садржи и потенцијал за стварање (Шевалије - Гербран 1989: 179), он машта о поновном рођењу које ће уследити након сваке доживљене „мале смрти” (Уп.: Батај 1962: 100; 106-107). За Шањија није циљ да нестане у ништавилу, већ да се опет обнови. У основи потребе за обновом јесте жеља да доживи гранично искуство као ново и испуњавајуће збивање које

\footnotetext{
${ }^{1}$ Павловићу се може замерити све оно што Лус Иригарај истиче као кључне показатеље неразумевања женске сексуалности (Иригарај 1985: 23-33, али и каснија поглавља). Међутим, чини се да је он и свестан своје нераскидиве везаности за мушку перспективу. У целом циклусу готово да не покушава да прикаже жену изнутра, а када то чини одлучује се за, на пример, Душицу, која се ослободила своје женствености, или Ержабет, која се сасвим утопила у улогу Мајке и негира вредност и специфичност свог пола. Свака сексуално активна жена (рецимо, у овом роману, Зулејха) приказана је из мушке перспективе као недоступна тајна.
} 
ће га тргнути из учмалости и свакодневног понављања раније утврђених модела понашања.

Са друге стране, Славољуб не жели ново постање већ утонуће у ништавило. Начин који Славољуб проналази како би спојио уживање и потпуно ишчезнуће јесте анални секс, који за њега означава свесно бирање бесмисла и потврду нестанка за којим жуди. Инсистирањем на аналном сексу, биолошка, репродуктивна функција тела је потиснута, човек се потврђује као биће мисли и воље, које жели да ужива у томе што нестаје без смисла. Кључне речи које можемо издвојити јесу уживање и ишчезнуће. Уживање представља потврду бирања садашњег тренутка, уместо потенцијалног улагања у будуће време, до кога би, у конкретном случају, могло довести другачије коришћење сексуалног нагона. Задовољење долази упркос свести (или баш захваљујући њој) о расипању у неплодан простор из кога се неће развити ништа. То задовољење је и физичко и духовно и интелектуално. Славољуб га проживљава телесно, а потом његову функцију себи (и Велимиру) објашњава.

Славољуб покушава да се ослободи понашања у коме има циљ и избегава бол ${ }^{2}$, али жели да укине онај бол који је последица крвице (Делез 1999: 153), и због тога настоји да тежи уживању као јединој сврси живљења и одбија да било коме шта дугује. ${ }^{3}$ Када осети да улази у оквире у којима задовољава туђу потребу за смислом, он настоји да побегне. Зато он себи, када Зулејха, родивши дете, полако постаје „Матер, сажегавши у себи све што је до јуче било Жена”, поставља питање: „Да ли сам ја шминкер који се заноси било каквим изиљевима?” (Павловић 1993: 328). Постојање циља и планирање животне сврхе он везује само за оне људе који се претварају пред собом, одбијајући да се суоче са испразношћу и ништавилом. Код њега нема идеализације циљева. Конкретно, ако Славољуб свира, он то ради да би себи обезбедио новац да може да финансира своје уживање. ${ }^{4}$ Ако га Зулејха привлачи, то је зато што се у њој бол и задовољство мешају, тј. тамо где друге жене осећају бол Зулејха осећа задовољство:

\footnotetext{
${ }^{2}$ Видети Ничеова разматрања о афирмативној улози бола у Вољи за моћ: фрагменти: 660-675; 693-703.

${ }^{3}$ Реч за дуг и кривицу у немачком језику је иста (Schuld), на чему Ниче инсистира у Генеологији морала.

${ }^{4}$ У античкој Грчкој, ако се ослањамо на Галенове ставове, сексуално уживање се схвата скоро као патолошка појава (ФУКО 1986: 139). То је важно јер се овај готово стоички приступ преноси на хришћанство и западну цивилизацију која се на хришћанству темељи. Да би опстало, друштво подржава наметнуте идеје и избегава деструкцију. Уживање, готово неминовно, одводи у разарање постојећог система, јер занемарује очекиване облике понашања у случају да они не доприносе остварењу задовољства. Конкретно, сексуално уживање постављено као једини циљ разара породицу, која представља основну ћелију организовања друштва.
} 
Све ређе с њом, све чешће с другима. Арапкиње, Африканке, Јапанке; мале, слатке, жуте из Бангкока, чоколадасте с Тахитија. Допадну ли ми се, одводио бих их у хотел и гузио. И само тако: у дупе, Велимире. У буљу! У пркно росно и радосно. Пичка - млитава чарапа, млака сласт, мљацкава бара без муње, без грома. Тесна гуза - опој прави. Натицао сам их на курац где год сам стигао и кад год сам могао. Мада - признаћу ти - с њима није ни изблиза било слатко као са Зулејхом. Оне су ме подносиле; она је уживала. Ниједна од свих тих безбројних гузица приликом јебачине није хтела да држи очи отворене! Жмуриле су! Стезале зубе и једва чекале да се истресем, па да се покупе и оду... А Зулејха... Шта Зулејха? Кад сам с њом, онда сам био само с њом. Дишеш и јебеш тамо где си... (Павловић 1993: 325)

Фасцинација Зулејхом долази отуда што Славољуб први пут не осећа само да се излива у празнину, већ посматра и Зулејхино уживање у чину које друге жене само трпе. За Зулејху, посматрану из Славољубове перспективе, бол није бол већ је уживање, ${ }^{5}$ и то не само у теоретском већ и у практичном облику. Поглед који би у класичном смислу требало да спаја љубавнике током њиховог срастања преломљен је кроз огледала јер у положају у ком су она њега не може гледати у очи: „Посматрала ме је у огледалу, зеница замућених димом тајанства - црне рупе у космосу. Ja: Заратустра и Надчовек. Она: васиона, бескрај и ништа. И тако сваке вечери" (Павловић 1993: 324). Гледање у Зулејху јесте потврда ничеанског активног нихилизма - срастања са бесмисленошћу живљења и прихватања несхватљивости постојања. ${ }^{6}$ Затварање очију представља начин на који човек одбија да се суочи са празнином. Не видети празнину значи не признати да је она ту и истрпети ударе таласа бесмисла, током којих ће друге жене стиснути зубе као да трпе бол, а онда отићи у потрагу за новим смислом. Зулејхине очи су, док га отворено посматра током сексуалног чина, ,замућене димом тајанства - црне рупе у космосу”.

Она је необјашњива, пред њим се отвара бескрајна и празна, јер само у њој може видети да пропада у ништавило. Чак и док је са њом само разговарао у продавници сексуалних помагала где је радила, у њеним зеницама „ковитлале су се тама и тајна”. Ово бива јер он неће разумети оно што њу одваја од осталих жена које је упознао - неће схватити њено уживање без мере. Њему је оно недоступно и несхватљиво јер он разуме само продирање фалуса и бол као женску реакцију на то продирање (Чизом 1995: 24). Зулејха изокреће игру, она постаје бескрај, који се константно шири и прети да га прогута. Њено тело се у његовим очима буквално претвара у космос, чиме се апсолутизује доживљај жене као простора. Она

\footnotetext{
${ }^{5}$ Упоредити са разматрањем мешаних осећања из Платоновог дијалога Филеб.

${ }^{6}$ Не треба ипак изгубити из вида да Славољуб није потпуни нихилиста, баш зато што жели ништавило. Желети ништа, ипак значи желети нешто.
} 
није контролисани познати простор куће, који се традиционално везује за Мајку, она постаје изразито сексуализована Жена, којој он не може да препозна границе јер нема познате оквире да је у њих смести (Бест 1995: 183). Треба разумети још нешто - гледање у Зулејхине очи у огледалу и пропадање у њих наступа док Славољуб телесно продире (пропада?) у њу. Насупрот ономе што износи Башлар (Башлар 1994: 184), код Славољуба пут у бескрај није производ физичке непокретности која омогућава неограничено ширење у простору маште. Он не машта, он ГЛЕДА у бескрај. Гледање је, за разлику од виђења, процес који траје. Докле год је у стању да се физички креће током сексуалног чина, моћи ће и да види, готово као да је увучен у покретање филмске траке. Зулејхине очи, на тај начин, постају синегдоха, оне носе значење целог њеног тела, које је једнако несхватљиво као и космичко пространство, иако је пред њим отворено. Управо та несагледива отвореност жене/простора и постаје загонетка.

Несагледивост Зулејхиних очију, које за њега постају представа космоса, долази из њене двоструке природе. Жену упознаје у продавници сексуалних помагала док купује часописе за Велимира. У том тренутку повучен, несигуран и сексуално неискусан, Славољуб улази у радњу и покушава да се заклони од онога што види и чује, казујући: „Али са мном, са мојим стидом и мојим страхом, то није имало никакве везе. Пуном снагом, свим силама, свим расположивим средствима опирао сам се да их буде. У оном смислу у коме грађанин жели да нема никакве везе са космосом" (Павловић 1993: 311). Занимљиво је приметити да га кретање ка Зулејхи буквално одводи од понашања пристојног грађанина ка мислима о космосу и ништавилу.

Раскидање са грађанским конвенцијама прати и понашање супротно од очекиваног и изолованог доживљаја сопственог бића као заштићеног од света: „Заклоњен одећом. Зидовима. Топлотом. Илузијама. Уверењем. Културом, Велимире. Тако и ја. Трудио сам се да не видим ништа. И не чујем ништа" (Павловић 1993: 311). Ако се уклони све што је Славољуб поменуо као омотаче, уклања се све што представља модерног цивилизованог човека. Када се уклоне слојеви које Славољуб помиње, требало би да остаје примитиван човек, али то није сасвим тачно. Примитиван човек тежи самоодржању и инстинктивно жели и одржање врсте. Славољуб жели излазак из човеку прирођених биолошких оквира, он жели да види ништавило - да га гледа очи у очи. Његов главни циљ постаје задовољство (Батај 1962: 11). Он тежи томе да поништи свој идентитет, који је друштвени конструкт. Ако је онај који има утврђен идентитет заправо онај који разликује себе од простора (Грос 1994: 48), онда је ишчезнуће у 
бескрајном простору (космосу, тј. жени) вид поништавања тог идентитета (Батај 1962: 31).

Зулејха ради у продавници сексуалних помагала и чита књигу о Моцарту, што је одмах чини привлачном за младог музичара. Привлачност долази из неочекиваног, из њене неуклопљености у простор, еротску жељу готово увек и изазива искакање из познатог и конвенционалног (Епштејн 2009: 118). Да је она кокетирала са муштеријама и привлачила пажњу својим телом, то би, у окружењу у које је смештена, било неизазовно понашање, јер је предвидиво. Овако њега не привлачи њено тело, напротив, у првом моменту једва да је и запажа, него неочекивана књига коју чита, а затим и њен поглед. Тек након таквог првог сусрета, он може снажно реаговати пошто касније у својој соби открије слике у купљеном часопису, где је она јунакиња низа сексуалних сцена са тамнопутим партнером:

Од бола, изазваног продирањем огромног курца у чмар, њени су се заобљени образи стезали грчевито, а меке усне кривиле у гримасу неизмерне патње. Док су очи, отворене широм, откривале бездан зеница по коме су попут магли, колала недефинишућа тајанства женског бића препуштеног понижењу као највећој могућој сласти. Је ли то иста жена? (Павловић 1993: 316)

Да се прво задржимо на болу. Славољуб жели да види бол, он нараста у телу и на фотографијама постаје видљив за друге, добијајући статус објекта (Скери 1985: 28). Он тежи томе да у другоме створи бол, а његово насиље није само физичко (у случају секса), већ и вербално (када препричава све што је видео и радио). Насиље има за циљ да поништи конвенције: сексуалне, дејством тела, и друштвене, дејством прича о телу. ${ }^{7}$ И једно и друго поништавање одвешће ка новој потврди његове тезе о бесмислености живота. Славољуба не узбуђује да изазива чист бол, јер онда себи ускраћује могућност за потпуно задовољство. Он жели да у партнерки произведе мешање бола и уживања, за које он верује да ће жену одвести ка „понижењу као највећој могућој сласти”. Управо га ова двострукост коју наслућује, јер је уочава на сликама, и фасцинира у Зулејхи.

Она ће од њега захтевати да се пре односа окупа. Правећи алузије на религију и Дантеову Божанствену комедију, смештајући је у сексуални контекст, он казује: „Дуго сам оклевао да крочим из Чистилишта. Нисам знао куда ме путеви даље воде. Да ли у Рај, или у Пакао?” (Павловић 1993: 321) Мешање религиозног и сексуалног од раније узбуђује Славољуба. На једном месту сећа се и представе из часописа који га је Велимир некада терао да гледа, уживајући у Славољубовом дечачком стиду:

${ }^{7}$ Упоредити са оним што Батај казује како је насиље у основи сваког еротизма (Батај 1962: 16). 
Сећам се: прво што сам видео, и што и најбоље памтим: самостан. Полусветло. Свеће. Путири. Канделабри. Распећа. Скулптуре анђела. Слике светаца. И молитве младих, плавооких опатица, пуних побожне чедности. Глума одлична. [...] поверовао сам, за трен, да то преда мном није некакав срамни игроказ, већ истина. То су, за мене, тад, те младе опатице заиста молиле. Заиста ходале смерно. Заиста биле окренуте Узвишеном. Затим су вечерале скромну испосничку храну у аскетској трпезарији, под Распећем. На крсту је, изнад огњишта, висио Христ - крвави атлета, болно сладострасног израза у изокренутим очима. Готово жив - толико је скулптура изгледала уверљиво. После, опатице су се разишле по ћелијама. Онда су свлачиле своје монашке ризе спремајући се за починак. Испод црних кукуљача израњала су привлачна тела: ноге, трбуси, груди, длаке. Дух и мистичност смењивала је пут (Павловић 1993: 312).

Када погледамо само речи наглашене курзивом, јасно је да је емоција интензивна управо јер Славољуб као младић верује у истинитост онога што види. Верује прво у искреност вере монахиња и њихову посвећеност богу, а затим и у поступно буђење њихових тела где се духовна посвећеност полако претвара у телесну глад. Кључни окидач за младићево узбуђење представља његова збуњеност, то што верује да обе ствари у исти мах заиста бивају - да се жене у једном тренутку моле и живе аскетски, док се у следећем самозадовољавају жудећи за оргазмом. Али слика се не зауставља на томе, за Славољуба врхунац узбуђења представља то што оне у сексуалном грчу са собом замишљају свеце којима су се мало пре тога молиле и једна од њих, која општи са Исусом „застрашујуће” га подсећа на сестру, што сугерише постојање потиснутих инцестуозних жеља.

Размишљајући о женама које се сликају за порнографске часописе, допуштајући, притом, да се првобитне илузије о љубави и сексу као чину интимног спајања замене сексуалношћу која представља представу за друге, Славољуб закључује како оне то „не чине само за новац, већ и на сопствену чудну, самопонижавајућу, гадну, у глиб поринуту, ослобађајућy насладу, која их, дефинитивно, лишава било каквог стида и било којих обзира. Бацајући их, кроз хаос, у окриље космоса" (Павловић 1993: 314). Ослобађање од стида, по Славољубовом мишљењу, јесте једини пут ка слободи, а слобода је ништа друго до ишчезнуће. Како би се ослободио стида, он мора превазићи свој првобитни младалачки страх од секса, јер је то подручје у коме је његов стид апсолутан - у сусрету са женама он није у стању да доживи довољно узбуђења да до сексуалног чина уопште дође, иако за тим жуди: „Не бити збуњен. Савладати стид. Истурити се. Изложити душу као неопрану гузицу! За то треба више снаге него да се родиш, стрикане; свет испред нас недохватљив је - не вреди труда? Ма шта учинио, на крају си опет у гробу у који те је кева рођењем положила!” (Павловић 1993: 291-292). 


\section{3. Анални секс и самопоништење - тело између страсти и гадости}

Апсолутна слобода за Славољуба значи прихватање немогућности спасења, и у складу са тим, тежњу ка истребљењу. Ако се вратимо на наведене одломке приметићемо да је кључна реч коју он везује за сазревање - уништење. У сексуалном чину, током којег се одбацује стид, човек жели да уништи жену; да би потврдио своју светост треба да уништи другог човека; док жена, са друге стране, мора да ужива у сласти претрпљеног разарања. Обичне жене које трпе, али не уживају, не привлаче Славољубову пажњу јер само ове које уживају прекорачују границу женствености. Када Фуко у својој Историји сексуалности говори о љубави према дечацима у античкој Грчкој, он запажа да је било непожељно да дечак ужива у сексуалном односу (Фуко 1985: 224). Ово истичемо јер, током аналног секса, жена губи своју биолошку функцију, може се готово свести на улогу грчког дечака, који треба да буде пасивни трпилац, а у најбољем случају, ужива јер обезбеђује уживање партнеру. Уживање које се у том тренутку јавља је чудна грешка, што улази у простор неконвенционалног и необјашњивог понашања. За Славољуба таква жена која ужива постаје светица, он верује у мистичко искуство самопоништења које му она открива. Врхунац разарања догађа се током аналног секса, тада активни човек улази у још један простор апсолута - апсолутну гробницу:

Да сам био на твом месту, ниједну јебачину не бих изводио другачије него преко тих оргуља. Нема партитуре чију и најзапетљанију мелодију не би могао да одсвираш на најбољи, најлуђи, најубитачнији начин! Нема секса без ануса, Вељо. Нити шеве ако није започета у тој дубокој и тесној шпиљи између два бела облака! После, кад дофураш до транса, кад се обезнаниш, свеједно је у шта ћеш да штрцнеш своје бело семе: у материцу, у грло, или у дебело црево - свеједно! Важно је где си, човече! А ти си тад, док је рокаш у чмар (у нашу људску клоаку из које се свакодневно одливају гомиле житких гована) - ти си усред ништавила. И тебе, тада, више но икад, можда више но и у смрти - НЕМА, ЧОВЕЧЕ! Нестајеш. Мешаш се са говнима. И сам постајеш говно. И ишчезаваш. Дивота. Срећа. Крајњи циљ живљења. Мог. Твог. Свачијег.. Тад, и само тад, она постаје наша апсолутна гробница. ЖЕНА, natürlich... И онда - шта те брига шта осећа, како реагуje? Зар тад, док ријеш по тим јаловим рудницима, има места ма каквом питању, ма каквим обзирима? Може да ћути, да се смеје, да плаче, да скичи, да урла, да скапава, да умире - шта се то тебе тиче? Тад, и само тад, кад је рокаш, кад је окидаш, шевиш, растураш, кад је гузиш, кад је јебеш У ДУПЕ, само у том вечном трену она заиста престаје да постоји (Павловић 1993: 322).

Иако је то јасно кроз целу Славољубову исповест, овде се можда најјасније види преклапање порнографског и филозофског. Насупрот Душици, која тежи томе да открије вечност и бескрај кроз личан однос 
са својим братом, са којим она верује да гради засебан свет у музици, он жели да у сексу оствари макар привремено вечну смрт тако што ће доћи до ништавила које му илуструје како изгледа вечност. За њега је однос са женом у датом моменту безличан у тој мери да га не занима ни шта она осећа ни како реагује, јер је једино чему тежи да је поништи као биће.

Славољуб се неће зауставити на деконструисању смисла секса већ ће и самог себе „снизити”. Као музичар, он представља анус као свој инструмент на коме се може све одсвирати. Музика као најапстрактнија уметност, можда је и најцењенија међу лажном елитом јер излази из оквира конкретног. Славољуб ће, уместо тежње ка апстрактном, па самим тим, како се то традиционално схвата, и узвишеним, одабрати да следи народну мудрост - колико пара толико музике. Али ту није крај. Средство за достизање апстракције су инструменти. Ако анус постаје инструмент, испоставља се да је на место врата ка апстрактном, до којих у идеалистичком виђењу одводи стапање са музиком, дошао анус који одводи до стапања са фекалијама. Уместо да открива апстрактно и узвишено, уметник постаје онај који одводи у конкретно и потапа слушаоца/читаоца директно у нуспродукт живљења, самим тим што су слике које ствара довољно јаке и неочекиване да су неизбрисиве из свести. У складу са тим, не чуди да он, склон срозавању онога што се иначе у друштву мора поштовати, бира поређење са оргуљама које се асоцијативним путем првенствено везују за цркве.

Мешање са фекалијама, које долази као последица аналног секса, потврђује тежњу активног учесника сексуалног односа ка стапању са ништавилом. Али откуда фокус на измету, а не на уживању? Одговор проналазимо у томе да ова два - оно што је уобичајено третирано као гадно и кретање које ће довести задовољства - тек обједињени омогућавају потпуни доживљај. Битно је имати у виду оно што је истакао и Свети Августин: „Рађамо се између фецеса и урина.” Како Батај примећује, не сме се занемарити веза између измета и сексуалности (Батај 1962: 58).

До сада је већ јасно да тела код Павловића никада нису чиста, нити то треба да буду. То нису тела која људи представљају другима, трудећи се да прикрију слабости и недостатке тела као механизма. Исто тако, Павловић не ствара ликове које треба да волимо, већ оне које треба да ВИДИМО. Они су уочљиви јер су огољени, а како у тој огољености нема поетизовања неретко могу изазвати гађење (или сажаљење, које је један облик гађења према слабијима од себе). Јунаци са којим се суочавамо нису улепшани, нису фотошопирани, а такав није ни језик од кога су изграђени. Они су 
живи и наглашено је све оно што их чини живима - физиолошки процеси који се у њима одигравају.

\section{4. Закључак - ништавило и светост}

Занимљиво је приметити да, ако посматрамо Славољубове критеријуме за светост (за мушкарце убиство другог човека, за жене уживање у сексу), његови родитељи, Ружа и Адам, обоје постају свеци. Адам убија другог човека; мајка ужива у задовољавању својих страсти, а, како сазнајемо од Душице, Ружа занемарује децу као случајне последице својих тренутних наслада. Иако је на ивици да закључи за себе како постоји као производ односа двоје светаца, ако тај појам схватимо у складу са његовим дефинисањем појма светости, Славољуб ипак не опонаша њихов приступ када је о деци реч. Сам говори Вељи како га је Зулејха везала за себе децом и како су му они били „Ахилова пета” (Павловић 1993: 326). Самим тим, ако Зулејха, рођењем детета постаје, уместо Жене, Мајка, и он је у опасности да уместо Мушкарца, постане Отац. Коначни бег од ове улоге за њега означава победу слободе избора, која за њега јесте прихватање онога што одређује као „радост ништавила”.

Враћајући се натраг у исту тачку из које је кренуо, Славољуб је задовољан што се тако кретао: „И ево ме, стрикане мој, у старом замку сред тамних германских шума тајанствених као време: круг се затворио. У чијем сам центру опет ја. Сам. Слободан” (Павловић 1993: 339). Потреба за слободом и бекством од наметнутих улога у Славољубу ће доживети врхунац на дан сопствене свадбе, када у соби надрогиране ћерке свог пословног партнера види „црним фломастером исписану девизу генерације која је на време схватила све": МИ СМО ГЕНЕРАЦИЈА БЕЗ ЖИВОТА/ ПРОШЛОСТ МРЗИМО/ САДАШњОСТ ПРЕЗИРЕМО/ А НА БУДУЋНОСТ НЕ МИСЛИМО (Павловић 1993: 339).

Схватити све за њега значи схватити да нема ничега и да ништа нема смисла. Уз то, неопходно је свесно одабрати ништавило, бити тело које бира да негира само себе. Коначно, бити сам, што Славољуб наглашава као идеал, јесте, ако се сетимо Ержабетине тврдње са почетка романа да је самоћа само за бога, стављање себе у ту, божанску, позицију. За Славољуба је суштина света спознаја ништавила, а посматрано из те перспективе, ако је он човек који гледа у ништа и схвата да је све ништа, он може бити и бог, који поседује свезнање и зна шта је у језгру света као да га је сам и створио. 


\section{ЛИТЕРАТУРА}

Батај 1962: G. Bataille, Death and Sensuality, New York: Walker and Company.

Башлар 1994: G. Bachelard, The Poetics of Space, Boston: Beacon Press.

Бec 1995: S. Best, Sexualizing Space, Sexy Bodies, ed. Elizabeth Grosz and Elspeth Probyn, London, New York: Routledge, 181-195.

Гpoc 1994: E. Grosz, Volatile Bodies, Bloomington and Indianapolis : Indiana University Press.

Делез 1999: Ж. Делез, Ниче и филозофија, Београд: Плато.

Епштејн 2009: М. Епштејн, Филозофија тела, Београд: Геопоетика.

Иригараj 1985: L. Irigaray, This Sex which is not the One, trans. Catherine Porter with Carolyn Burke, Ithaca, New York : Cornell University Press.

Кристева 1987: J. Kristeva, In the Beginning was Love: Psychoanalysis and Faith, New York: Columbia University Press.

Ниче 1991: Ф. Ниче, Воља за моћ, Београд: Дерета.

Ниче 2001: F. Niče, Genealogija morala, Nova Pazova: Bonart.

Павловић 1993: Ж. Павловић, Задах тела, у: Дивљи ветар, књига 5, Нови Сад: Знање, Београд: Квит подиум.

Павловић 2001: Ž. Pavlović, Jahač na lokomotivi, razgovori sa Živojinom Pavlovićem, priredio Nebojša Pajkić, Beograd: SKC.

Платон 1975: Plato, Philebus, London: Oxford University Press.

Скери 1985: E. Scarry, The Body in Pain, New York: Oxford University Press.

Фуко 1985: M. Foucault, The History of Sexuality, vol. 2, The Use of Pleasure, Random House, New York.

Фуко 1986: M. Foucault, The History of Sexuality, vol. 3, The Care of the Self, New York : Random House.

Чизом 1995: D. Chisholm, The 'Cunning Lingua' Of Desire: Bodies Language And Perverse Performativity, Sexy Bodies, ed. Elizabeth Grosz and Elspeth Probyn, London, New York: Routledge, 19-42.

Шевалије, Гербран 1989: J. Chevalier, A. Gheerbrant, Rječnik simbola, Zagreb: Nakladni zavod MH. 
Natalija P. Jovanovic

\title{
"MISUSING" THE BODY - VANISHING AS THE ULTIMATE PASSION IN ZIVOJIN PAVLOVIC'S NOVEL BODY SCENT
}

\begin{abstract}
Summary
In this paper we pointed out the relations between body, sexuality and nothingness, which are represented in a chapter of Body Scent, the novel by Zivojin Pavlovic. We researched the position of the body in the novel, as well as the ways of forming complex system of reflections about corporeality, and, finally, the key points of authentic philosophy of the body created by the novel's central character. We insisted on the connection which is established between sexuality, disgust and (self-)destructiveness and concluded that, if we adopt the point of view of the novel's central character, absolute freedom can be reached only by the fusion of this elements.
\end{abstract}

Key words: body, sexuality, nothingness, absolute freedom, disgust, Body Scent 